\title{
Glucagon, insulin and somatostatin secretion in response to sympathetic neural activation in streptozotocin-induced diabetic rats. A study with the isolated perfused rat pancreas in vitro
}

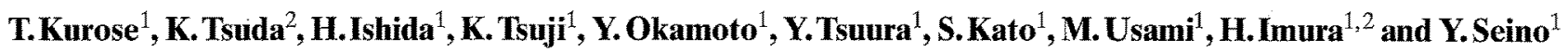 \\ ${ }^{1}$ Department of Metabolism and Clinical Nutrition, and ${ }^{2}$ Second Division, Department of Internal Medicine, \\ Kyoto University Faculty of Medicine, Kyoto, Japan
}

\begin{abstract}
Summary. Changes in glucagon, insulin and somatostatin secretion induced by electrical splanchnic nerve stimulation were examined in rats treated with streptozotocin as neonates and as adults. In order to study the direct neural effects we used the isolated perfused rat pancreas with intact left splanchnic nerve in vitro. In normal rats splanchnic nerve stimulation causes significant decreases in insulin $(30-40 \%)$ and somatostatin $(30-50 \%)$ secretion at both $16.7 \mathrm{mmol} / 1$ and $1 \mathrm{mmol} / \mathrm{l}$ glucose concentrations. In the neonatal streptozotocin-diabetic rats splanchnic nerve stimulation at $16.7 \mathrm{mmol} / \mathrm{l}$ glucose decreased insulin secretion $(14 \%)$ further than in the control rats $(30 \%)$, however, somatostatin secretion did not decrease to the same extent. Similar results were also observed at the low ( $1 \mathrm{mmol} / \mathrm{l}$ ) glucose concentration. On the other hand, percent decreases of insulin and somatostatin secretion induced by splanchnic nerve stimulation in the streptozo-
\end{abstract}

tocin-diabetic rats were similar to the values observed in the normal control rats. The glucagon secretion in response to splanchnic nerve stimulation at $16.7 \mathrm{mmol} / \mathrm{l}$ glucose from pancreatic Alpha cells in both types of induced diabetes is exaggerated, and the degree of exaggeration seems to parallel the severity of the hyperglycaemia. However, the splanchnic nerve stimulation-induced glucagon secretion at $1 \mathrm{mmol} / 1$ glucose was impaired in the streptozotocin-diabetic rats, but not in the neonatal streptozotocin-diabetic rats. These data suggest that the sensitivity of diabetic Alpha and Delta cells to sympathetic neural activation are blunted, whereas the sensitivity of Beta cells is enhanced in the diabetic animal model.

Key words: Glucagon, insulin, somatostatin, streptozotocin, sympathetic nerve, diabetic rat.
It has been reported that various clinical stress states are associated with catecholamine excess and hyperglycaemia, resulting in impaired insulin secretion and hyperglucagonaemia $[1,2]$. Furthermore, exaggerated glucagon responses to epinephrine have been observed in diabetic patients [2], and this exaggeration of glucagon secretion may have clinical importance in the pathogenesis of diabetes mellitus [3]. On the other hand, pancreatic Alpha-cell responses to changes in glucose concentrations are also abnormal in diabetes [4].

Portha et al. [5] and Weir et al. [6] have reported independently that rats receiving streptozotocin during the neonatal period show a resemblance to human Type 2 (non-insulin-dependent) diabetes with a mild diabetic state showing selective insensitivity to glucose in Beta cells, while insulin secretion in response to other secretagogues is preserved. Furthermore, adult rats receiving streptozotocin develop severe insulin deficiency, and are considered to be one of the models of Type 1 (insulin-dependent) diabetes [7].
In the present study we have investigated the effect of sympathetic neural activation on the endocrine pancreas in the animal models of diabetes. Furthermore, in order to elucidate the mechanism of abnormal glucagon secretion from diabetic Alpha cells in response to sympathetic neural activation, we have investigated the effect of glucose on glucagon secretion during splanchnic nerve stimulation in streptozotocin-induced rat models of Type 2 and Type 1 diabetes using isolated perfused rat pancreas with intact left splanchnic nerve in vitro.

\section{Materials and methods}

Neonatal streptozotocin rat model of Type 2 diabetes (NSZ)

Male, Wistar pups, 1.5 days old (Wistar-Jcl, purchased from Clea, Osaka, Japan) received $90 \mathrm{mg} / \mathrm{kg}$ streptozotocin s.c. (Upjohn, Osaka, Japan) and control rats received a diluent 0.05 mol/ citrate buffer. After weaning the animals received standard laboratory 
chow, water ad libitum in a temperature- and light-conditioned room for 12 weeks. The plasma glucose was measured at 12 weeks of age in blood obtained from the tail vein.

\section{Streptozotocin rat model of Type 1 diabetes (STZ)}

Male Wistar rats weighing $240-260 \mathrm{~g}$ received $50 \mathrm{mg} / \mathrm{kg}$ streptozotocin via injection into the jugular vein. The animals were maintained as above for 4 weeks, when the plasma glucose was measured.

\section{In vitro isolated perfused pancreas}

The animals were fasted overnight before the experiments when anaesthesia was induced by intraperitoneal administration of $6 \mathrm{mg} / 100 \mathrm{~g}$ body weight of sodium pentobarbital. The pancreas with intact left splanchnic nerve was isolated as previously described [8]. The perfusate of Krebs-Ringer bicarbonate buffer containing $4.6 \%$ dextran (mean mol. wt. 70,000; Pharmacia, Uppsala, Sweden) was equilibrated with $95 \% \mathrm{O}_{2}$ and $5 \% \mathrm{CO}_{2}$, and the $\mathrm{pH}$ was adjusted to 7.4. It was placed in a reservoir maintained at $37^{\circ} \mathrm{C}$. The glucose concentration was adjusted to the desired level by means of a side arm pump, and bovine serum albumin (fraction V; Sigma Chemical Co., St. Louis, Mo., USA) was also added to a final concentration of $0.25 \%$. The pressure of $\mathrm{O}_{2}$ in the perfusate ranged $450-500 \mathrm{~mm} \mathrm{Hg}$ $(59.9-66.5 \mathrm{kPa})$. The flow was non-recycling and the rate was usually $1.8-1.9 \mathrm{ml} / \mathrm{min}$ at a perfusion pressure of $40-60 \mathrm{mmHg}(5.3-$ $8.0 \mathrm{kPa}$ ), measured with the transducer (model T12; Gould Inc., Oxnard, Calif., USA). After surgery the perfused pancreas with left splanchnic nerve was placed in a temperature- and humidity-constant chamber. Each 1-min effluent from the portal vein was collected into chilled tubes containing $1000 \mathrm{U}$ of Trasylol (Bayer, Leverkusen, FRG), frozen immediately, and then stored at $-20^{\circ} \mathrm{C}$ until assayed.

\section{Experimental protocol}

After an equilibration period of $20 \mathrm{~min}$, samples were taken for $20 \mathrm{~min}$. Electrical splanchnic nerve stimulation (SNS) was performed for 5 min as $1 \mathrm{~ms}, 30$-V square wave impulses at a frequency of $10 \mathrm{~Hz}$. The completeness of the electrical SNS was confirmed by ascertaining an increase of more than $30 \mathrm{~mm} \mathrm{Hg}$ in the pressure of the arterial cannulation tube. For the study of the effects of SNS on glucagon, insulin and somatostatin at a high glucose concentration, the perfusate concentration of glucose was kept constant at $16.7 \mathrm{mmol} / \mathrm{l}$ throughout the entire experimental period, and SNS was performed $3 \mathrm{~min}$ after the start of sampling. In another experimental protocol, the concentration of glucose was reduced from $16.7 \mathrm{mmol} / \mathrm{l}$ to $1 \mathrm{mmol} / 3 \mathrm{~min}$ after the start of sampling, and SNS under the same conditions described above was performed at this low glucose concentration.

\section{Assay and data analysis}

The concentration of immunoreactive insulin was measured by RIA using a polyethylene glycol precipitation technique, with rat insulin (Novo, Bagsvaerd, Denmark) as standard [9]. Immunoreactive somatostatin was measured by specific RIA [10], with a modification of the method described by Arimura et al. [11], with antiserum T-316 and synthetic cyclic somatostatin (Takeda Pharmaceutical Co., Osaka, Japan) as standard. Antiserum T-316 was produced in a rabbit by repeated immunizations with synthetic cyclic somatostatin coupled to crystallized bovine serum albumin. T-316 had no cross-reactivity with insulin, glucagon, gastrin, motilin, vasoactive intestinal polypeptide, secretin, and substance-P. N-tyrosyl somatostatin was iodinated with ${ }^{125} \mathrm{I}-\mathrm{Na}$ by the chloramine- $\mathrm{T}$ method and subsequently purified on a Sephadex G-25 (fine) column. The minimum detectable quantity of the assay was 6 pmol/l. Immunoreactive glucagon was measured by RIA using the talcum adsorption technique of Sakurai et al. [12], with an antiserum specific for pancreatic glucagon (OAL-123; Otsuka Assay Laboratory, Tokushima, Japan). Porcine glucagon (Novo) was the standard. The minimum detectable quantity of the assay was $40 \mathrm{ng} / \mathrm{l}$.

The insulin, somatostatin, and glucagon outputs were calculated as the concentration of each hormone multiplied by the volume of each 1-min effluent. Percent basal was calculated as follows: the values for hormone outputs at each time during and after SNS were divided by the basal value at 2-3 min (hereafter expressed as 3 min) in the experiments at $16.7 \mathrm{mmol} / \mathrm{lglucose}$, or at $8 \mathrm{~min}$ in the experiments at the $1 \mathrm{mmol} / 1$ glucose concentration. These values were then multiplied by 100 to obtain the percentage. For the evaluation of the decrease in insulin and somatostatin outputs during SNS, the percent basal at nadir was calculated as the mean of the values at the lowest point in each experiment, i.e.

\section{$\Sigma(\%$ basal at nadir in each experiment $)$ (number of experiments)}

The total decrement beneath the basal level of insulin and somatostatin output and the total increment above the basal level of glucagon output are expressed as the sums of the difference between each value during the 5-min period of SNS and basal value just before SNS, i.e. $\sum\left(x_{i}-y\right)$.

Where $x_{i}$ represents each hormone output at $i$ min during the 5 -min period of SNS, and y represents basal hormone output just before SNS. These sums are expressed as negative values for decreases and positive values for increases.

\section{Statistical analysis}

Statistical comparisons of means within a group were made using Student's paired $t$-test. Comparisons between means of different groups were made by analysis of variance followed by Duncan's multiple range test [13], if the null hypothesis was rejected by the former. Differences were accepted as significant at $p<0.05$.

\section{Results}

\section{Body weight and plasma glucose}

Immediately before perfusion experiments, the body weight of the NSZ rats was identical to that of the control rats, but the body weight of the STZ rats was significantly lower than in the control rats $(p<0.01$, Table 1$)$. Plasma glucose levels of the NSZ rats fed ad libitum were significantly higher than the levels of the controls $(p<0.01)$, while fasting plasma glucose levels in the NSZ rats were not significantly different from the values in the controls. In the STZ rats ad libitum plasma glucose levels were significantly higher than the levels of the controls $(p<0.01)$, and fasting plasma glucose levels in the STZ rats were significantly higher than the levels of the controls $(p<0.01)$.

\section{$N S Z$ rats}

Effects of SNS at 16.7 mmoll glucose on insulin, somatostatin and glucagon secretion. The protocol and results are shown in Figure 1. After a 20 -min equilibration period insulin output at $16.7 \mathrm{mmol} / \mathrm{glucose}$ in the NSZ rats was significantly lower than in the control rats (Table 2). Insulin 
Table 1. Characteristics of the control rats, rats treated with streptozotocin as neonates (NSZ) and as adults (STZ)

\begin{tabular}{llcc}
\hline Group $(n)$ & Body & \multicolumn{2}{c}{ Plasma glucose (mmol/l) } \\
\cline { 3 - 4 } & weight $(\mathrm{g})$ & Fasting & Non-fasting \\
\hline NSZ $(10)$ & $255 \pm 14$ & $5.82 \pm 0.34$ & $10.25 \pm 0.50^{\mathrm{a}}$ \\
Control $(10)$ & $275 \pm 10$ & $5.60 \pm 0.22$ & $7.45 \pm 0.45$ \\
\hline STZ $(10)$ & $194 \pm 9^{\mathrm{a}}$ & $12.26 \pm 1.01^{\mathrm{a}}$ & $31.53 \pm 2.46^{\mathrm{a}}$ \\
Control $(11)$ & $303 \pm 9$ & $5.21 \pm 0.28$ & $7.62 \pm 0.34$ \\
\hline
\end{tabular}

${ }^{a} p<0.01$ vs control rats

Mean \pm SEM are shown

output rapidly fell from the pre-stimulatory level to a nadir at 5 min during SNS in both NSZ and control rats. The maximal decrease in the NSZ rats, $85.6 \pm 5.3 \%$, was significantly greater than in the controls $(p<0.05$, Table 3$)$. The pre-stimulatory levels of somatostatin and glucagon output in the NSZ rats were not significantly different from those in the controls (Table 2). However, the maximal decrease in somatostatin output induced by SNS was significantly smaller than in the controls. On the other hand, SNS caused the glucagon output at $16.7 \mathrm{mmol} / 1$ glucose to increase five-fold in the NSZ rats, whereas in the control rats SNS did not cause any change in glucagon output.

Effects of SNS at $1 \mathrm{mmol} / \mathrm{l}$ glucose on insulin, somatostatin and glucagon secretion. The protocol and results are shown in Figure 2. When the perfusate glucose concentration was lowered from $16.7 \mathrm{mmol} / \mathrm{l}$ to $1 \mathrm{mmol} / \mathrm{l}$, the insulin and somatostatin output in the control rats rapidly fell from the pre-stimulatory levels at $3 \mathrm{~min}$ to nadirs at $8 \mathrm{~min}$ $(p<0.01, p<0.05$, respectively). At this low level of glucose concentration SNS slightly reduced insulin output in both NSZ and control rats. The maximal decrease in insulin output during SNS in the NSZ rats was not different from that in the controls (Table 3). A small reduction of somatostatin output was induced by SNS in the control rats. However, although perfusate flow significantly decreased during SNS in the NSZ rats, somatostatin output showed no change. Acute reduction of glucose concentration did not cause any significant change in glucagon output in either group. SNS produced a 34-fold increase in glucagon output in the control rats. The response of glucagon output to the SNS in the NSZ rats was similar to that in the control rats. Furthermore, the total increment above basal level during SNS in the NSZ rats was comparable to that in the controls (Table 4).

\section{STZ rats}

Effects of SNS at $16.7 \mathrm{mmol} / \mathrm{glucose}$ on insulin, somatostatin and glucagon secretion. The protocol and results are shown in Figure 3. The STZ rats, as expected, had a significantly lower mean insulin output than the control rats at $16.7 \mathrm{mmol} / \mathrm{l}$ glucose. Somatostatin output in the STZ rats was also significantly lower than in the control rats. However, glucagon output at $16.7 \mathrm{mmol} / 1$ glucose in the STZ rats was higher than in the control rats, but the difference did not reach statistical significance (Table 2). Although the pre-stimulatory level of insulin output was very low, SNS slightly decreased insulin output in the STZ rats. Calculated maximal decrease in the STZ rats was similar to that in the control rats. The SNS caused a significant decrease in somatostatin output in both groups, and the maximal decrease induced by SNS in the STZ rats was similar to that in the control rats. On the other hand, while no significant change was observed in glucagon output during SNS in the control rats, a significant four-fold increase was observed in the STZ rats.

Effects of SNS at 1 mmol/l glucose on insulin, somatostatin and glucagon secretion. As shown in Figure 4, in the control rats the acute reduction of glucose concentration sig-

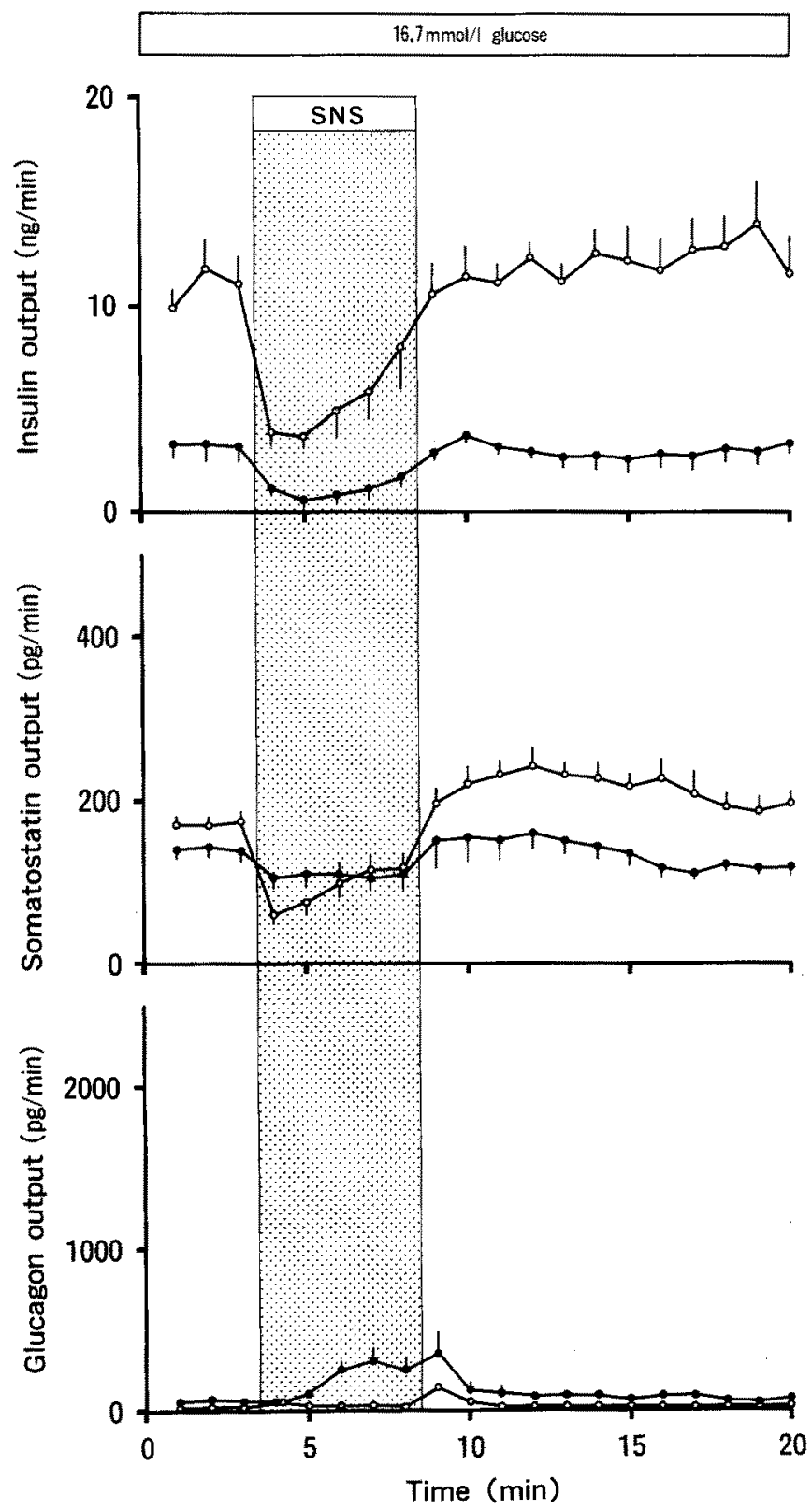

Fig. 1. Effects of splanchnic nerve stimulation (SNS) on insulin, somatostatin and glucagon secretion at $16.7 \mathrm{mmol} / \mathrm{l}$ glucose in rats treated with streptozotocin as neonates $(-)(n=5)$ and in control rats, $(0-0)(n=6)$ using the isolated and perfused pancreas. Mean \pm standard error are shown 
Table 2. Insulin, somatostatin and glucagon output at $16.7 \mathrm{mmol} / 1$ and $1 \mathrm{mmol} / \mathrm{lg}$ glucose

\begin{tabular}{|c|c|c|c|}
\hline Group (n) & $\begin{array}{l}\text { Insulin } \\
\text { (ng/min) }\end{array}$ & $\begin{array}{l}\text { Somatostatin } \\
(\mathrm{pg} / \mathrm{min})\end{array}$ & $\begin{array}{l}\text { Glucagon } \\
\text { (pg/min) }\end{array}$ \\
\hline \multicolumn{4}{|l|}{$\overline{N S Z}$} \\
\hline $\begin{array}{c}16.7 \mathrm{mmol} / \mathrm{l} \text { glucose }(10) \\
1 \mathrm{mmol} / \mathrm{l} \text { glucose }(5)\end{array}$ & $\begin{array}{l}3.39 \pm 0.59^{\mathrm{a}} \\
0.83 \pm 0.27^{\mathrm{b}}\end{array}$ & $\begin{array}{l}96.6 \pm 16.7 \\
41.5 \pm 8.3^{b}\end{array}$ & $\begin{array}{r}65.0 \pm 15.3 \\
137.6 \pm 30.0\end{array}$ \\
\hline \multicolumn{4}{|l|}{ Control } \\
\hline $\begin{array}{c}16.7 \mathrm{mmol} / / \text { glucose }(10) \\
1 \mathrm{mmol} / / \text { glucose }(4)\end{array}$ & $\begin{aligned} 13.07 & \pm 1.13 \\
0.53 & \pm 0.10^{b}\end{aligned}$ & $\begin{array}{c}135.7 \pm 12.4 \\
53.0 \pm 5.0^{\mathrm{b}}\end{array}$ & $\begin{array}{l}56.9 \pm 20.8 \\
96.9 \pm 66.5\end{array}$ \\
\hline \multicolumn{4}{|l|}{$\overline{S T Z}$} \\
\hline $\begin{array}{c}16.7 \mathrm{mmol} / / \text { glucose }(10) \\
1 \mathrm{mmol} / \mathrm{l} \text { glucose }(5)\end{array}$ & $\begin{array}{l}0.21 \pm 0.06^{\mathrm{a}} \\
0.18 \pm 0.07\end{array}$ & $\begin{array}{l}56.4 \pm 4.1^{\mathrm{a}} \\
50.4 \pm 7.7\end{array}$ & $\begin{array}{r}82.4 \pm 14.6 \\
118.5 \pm 29.4\end{array}$ \\
\hline \multicolumn{4}{|l|}{ Control } \\
\hline $\begin{array}{c}16.7 \mathrm{mmol} / / \text { glucose }(11) \\
1 \mathrm{mmol} / / \text { glucose }(5)\end{array}$ & $\begin{array}{c}10.94 \pm 0.57 \\
0.27 \pm 0.03^{b}\end{array}$ & $\begin{array}{r}137.6 \pm 15.2 \\
62.8 \pm 5.6^{b}\end{array}$ & $\begin{array}{r}43.0 \pm 13.4 \\
101.1 \pm 25.1\end{array}$ \\
\hline
\end{tabular}

${ }^{a} p<0.01$ vs control rats at the same concentration of glucose;

${ }^{\mathrm{b}} p<0.01$ vs the value at $16.7 \mathrm{mmol} / \mathrm{l}$ glucose in the same group of rats.

All results are expressed as mean \pm SEM. NSZ, Rats treated with streptozotocin as neonates; STZ, rats treated with streptozotocin as adults

nificantly decreased insulin and somatostatin output. However, the large reduction of glucose concentration did not affect the insulin and somatostatin output in the STZ rats. At $1 \mathrm{mmol} / 1$ glucose SNS caused a minimal decrease in insulin output in both STZ and control rats. Furthermore, SNS caused a small but significant decrease in somatostatin output in both groups. There was no difference in the maximal decrease of somatostatin output between the STZ and the control rats. As was observed in the control rats, the acute reduction of glucose concentration did not cause any change in glucagon output in the STZ rats. A large difference was observed, however, in the response of glucagon output during SNS in the STZ rats. The response of glucagon output to SNS at this low level of glucose in the STZ rats was significantly smaller than in the control rats, and in the STZ rats the total increment above basal level of glucagon output during SNS at $1 \mathrm{mmol} / \mathrm{lglu}-$ cose was similar to that observed at $16.7 \mathrm{mmol} / 1$ glucose (Table 4).

\section{Discussion}

In the present study we have observed that the glucagon response to SNS at a low glucose concentration was unchanged in the NSZ rats but was impaired in the STZ rats. Accordingly diabetic Alpha-cell sensitivity to sympathetic neural outflow is likely to be altered in relation to the degree of the severity of the diabetic state. A possible effect of STZ-induced insulitis on the decreased glucagon secretion is unlikely, since glucagon concentrations in plasma and pancreatic tissue were increased in the STZ rats [14]. Other possible contributing factors are diabetic autonomic neuropathy or an alteration in catecholamine sensitivity of diabetic Alpha cells. Schmidt et al. [15] and Anderson et al. [16], however, have reported that they failed to demonstrate axonal dystrophy of the autonomic nerves, a characteristic of diabetic neuropathy, in animals diabetic for 4 months or less, in marked contrast to the presence of axonopathy of the somatic nerves observed as early as 4 weeks after diabetes is induced [17]. Diabetic Alpha-cell sensitivity to catecholamines has been reported to be unchanged in NSZ rats [18] and in rats treated acutely with streptozotocin [19]. By contrast, an early alteration in the activity of the pancreatic sympathetic nerve has been reported. Reduction in both sensitivity to norepinephrine and availability of norepinephrine was observed only 2 weeks after the induction of diabetes with streptozotocin [20]. Furthermore, when autonomic neuropathy is present, the responses of the pa-

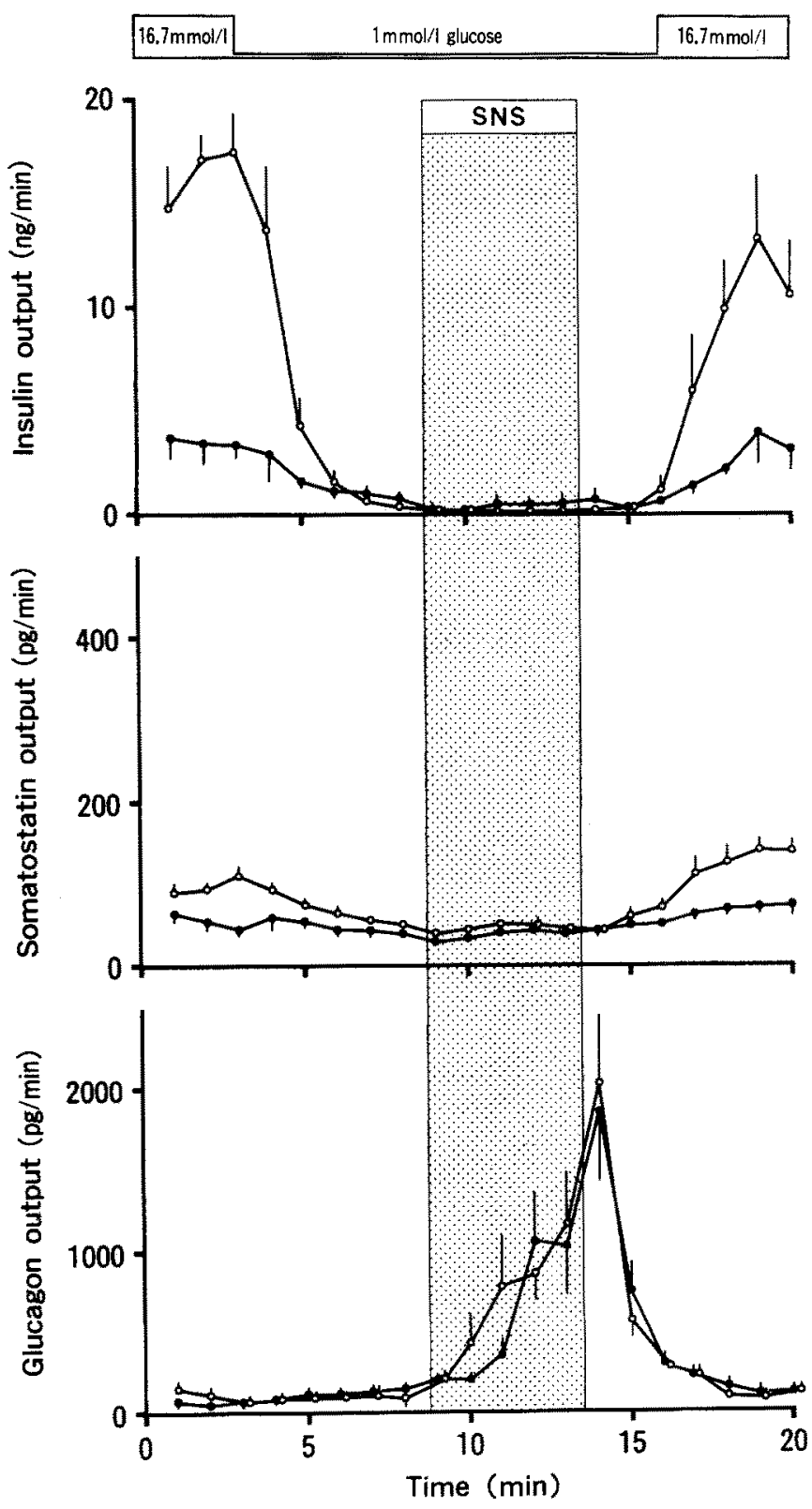

Fig. 2. Effects of splanchnic nerve stimulation (SNS) on insulin, somatostatin and glucagon secretion at $1 \mathrm{mmol} / \mathrm{glucose}$ in rats treated with streptozotocin as neonates $\bullet-(n=5)$ and in control rats $(0-0)(n=4)$ using the isolated and perfused pancreas. Mean \pm standard error are shown 
T. Kurose et al.: Sympathetic nerve and islet hormones in diabetes

Table 3. Percent basal at nadir during splanchnic nerve stimulation \begin{tabular}{lll}
\hline Perfusate condition Flow (\%) & Insulin (\%) & Somatostatin (\%)
\end{tabular} 16.7 mmoll glucose

\begin{tabular}{llll} 
NSZ & $88.0 \pm 4.1$ & $14.4 \pm 5.3^{\mathrm{a}}$ & $58.1 \pm 3.1^{\mathrm{b}}$ \\
Control & $71.5 \pm 6.7$ & $30.6 \pm 4.6$ & $36.0 \pm 6.2$ \\
STZ & $81.5 \pm 8.6$ & $30.8 \pm 10.6$ & $55.9 \pm 4.2$ \\
Control & $86.0 \pm 3.7$ & $34.1 \pm 8.5$ & $51.4 \pm 5.2$ \\
\hline
\end{tabular}

$1 \mathrm{mmol} / \mathrm{glucose}$

\begin{tabular}{lrrl} 
NSZ & $57.0 \pm 4.1$ & $8.1 \pm 2.6$ & $91.0 \pm 23.3$ \\
Control & $80.0 \pm 4.6$ & $22.3 \pm 8.1$ & $69.5 \pm 1.8$ \\
STZ & $68.7 \pm 6.0$ & $24.5 \pm 9.3$ & $48.3 \pm 10.7$ \\
Control & $64.0 \pm 4.8$ & $8.1 \pm 1.5$ & $44.4 \pm 6.0$ \\
\hline
\end{tabular}

${ }^{a} p<0.05,{ }^{b} p<0.01$ vs control rats. Mean \pm SEM are shown. NSZ, Rats treated with streptozotocin as neonates; STZ, rats treated with streptozotocin as adults

Table 4. Total decrements beneath basal level of insulin and somatostatin output, and total increment above basal level of glucagon output during splanchnic nerve stimulation in control, NSZ and STZ rats

\begin{tabular}{lccc}
\hline Perfusate condition & $\begin{array}{l}\text { Insulin } \\
(\mathrm{ng} / 5 \mathrm{~min})\end{array}$ & $\begin{array}{l}\text { Somatostatin } \\
(\mathrm{pg} / 5 \mathrm{~min})\end{array}$ & $\begin{array}{l}\text { Glucagon } \\
(\mathrm{pg} / 5 \mathrm{~min})\end{array}$ \\
\hline 16.7 mmol/h glucose & & & \\
NSZ & $-10.95 \pm 2.01^{\mathrm{a}}$ & $-170.6 \pm 33.6$ & $643.2 \pm 243.3^{\mathrm{a}}$ \\
Control & $-28.33 \pm 4.66$ & $-335.3 \pm 77.3$ & $72.0 \pm 32.3$ \\
STZ & $-0.39 \pm 0.14^{\mathrm{b}}$ & $-25.7 \pm 18.6^{\mathrm{b}}$ & $756.4 \pm 188.6^{\mathrm{a}}$ \\
Control & $-28.42 \pm 3.47$ & $-154.0 \pm 20.9$ & $181.8 \pm 81.8$ \\
\hline Immol/lglucose & & & \\
NSZ & $-2.18 \pm 2.27$ & $-1.3 \pm 45.3$ & $2124.6 \pm 836.2$ \\
Control & $-0.97 \pm 0.19$ & $-30.5 \pm 18.3$ & $2969.7 \pm 618.6$ \\
STZ & $-0.70 \pm 0.36$ & $-99.1 \pm 29.0$ & $1216.4 \pm 214.5^{\mathrm{a}}$ \\
Control & $-0.58 \pm 0.15$ & $-81.6 \pm 23.8$ & $2777.6 \pm 608.5$ \\
\hline
\end{tabular}

${ }^{a} p<0.05,{ }^{b} p<0.01$ vs control rats. All results are expressed as mean $\pm S E M$. NSZ, Rats treated with streptozotocin as neonates; STZ, rats treated with streptozotocin as adults

rotid gland [16] and the vas deferens [21] to sympathetic or noradrenergic nerve stimulation are reported to be reduced. Accordingly the decreased glucagon response to SNS at the low glucose concentration in the diabetic rats may be related to defects in the sympathetic nervous system and decreased Alpha-cell sensitivity to norepinephrine.

On the other hand, glucagon response to SNS is exaggerated at a high glucose concentration in the NSZ rats. The exaggeration of SNS-induced glucagon secretion at the high glucose concentration in this model might be related to an impaired inhibitory effect of glucose on glucagon secretion, since suppression of glucagon secretion by hyperglycaemia is a characteristic feature of normal Alpha-cell function, and impaired glucose suppression of glucagon secretion has been demonstrated in human diabetes [3] and in various animal models [6,22]. Another possible contributing factor may be the lack of the normal decline in intra-islet insulin in islets from streptozotocin-diabetic rats [23]. Furthermore, in the STZ rats with more severe hyperglycaemia and Beta-cell deficiency, this exaggeration of SNS-induced glucagon secre- tion at a high glucose concentration was also demonstrated.

The results of previous studies on the catecholamine sensitivity of the Beta cells in diabetes are controversial and inconclusive. $\beta$-adrenergic hypersensitivity of insulin secretion was reported in one study [6], but in others insulin response to $\beta$-adrenergic agonists was apparently unaltered in an in vitro system [24] or reduced in an in vivo system [25]. On the other hand, epinephrine suppressibility of insulin secretion from the isolated perfused pancreas was not altered in the NSZ rats when the baseline insulin secretion was matched to the controls by arginine infusion [18]. We observed a higher percentage decrease of insulin output in the NSZ rats than in the controls at the

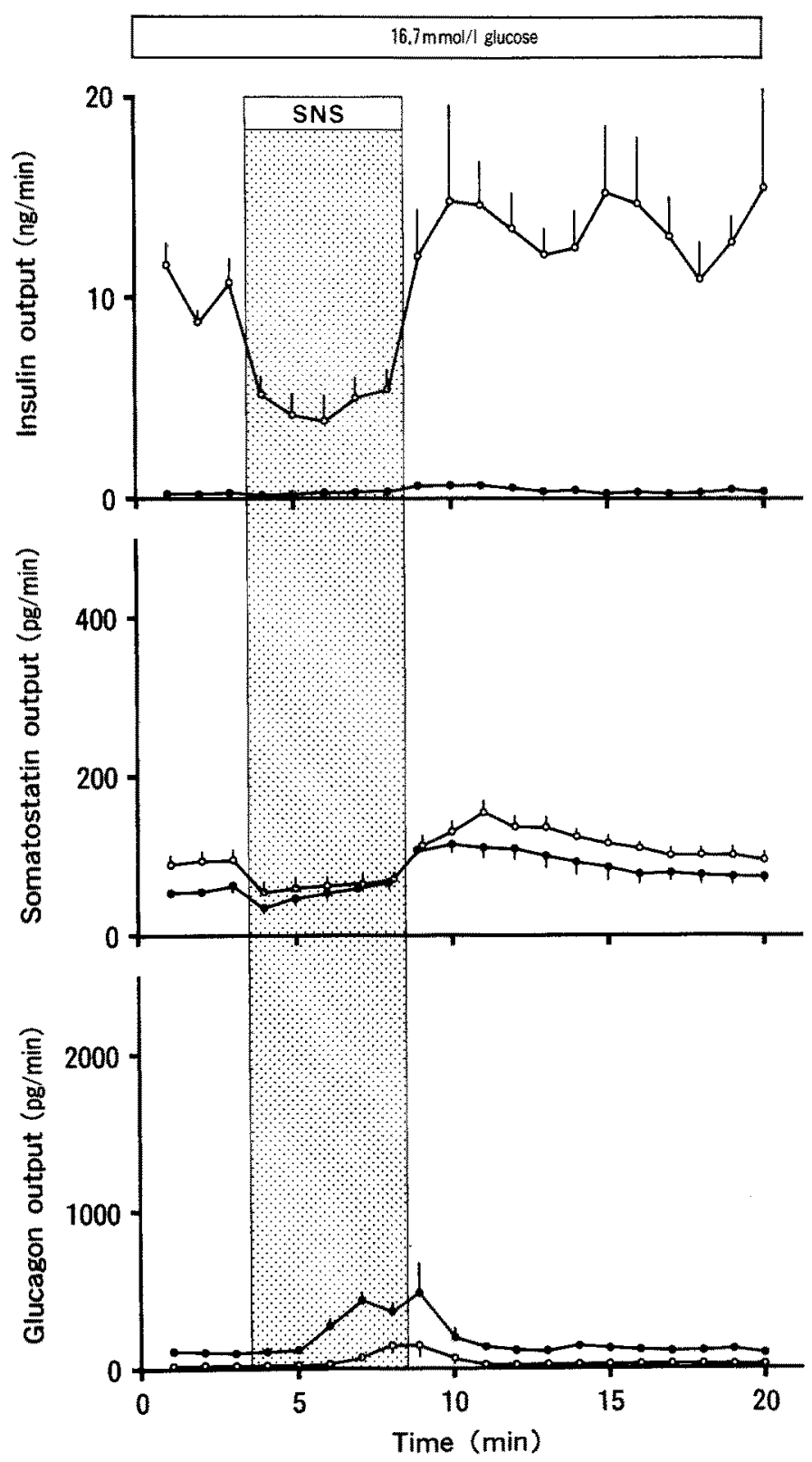

Fig.3. Effects of splanchnic nerve stimulation (SNS) on insulin, somatostatin and glucagon secretion at $16.7 \mathrm{mmol} / \mathrm{glucose}$ in rats treated with streptozotocin as adults $(-)(n=5)$ and in control rats $(0-0)(n=6)$ using the isolated and perfused pancreas. Mean \pm standard error are shown 


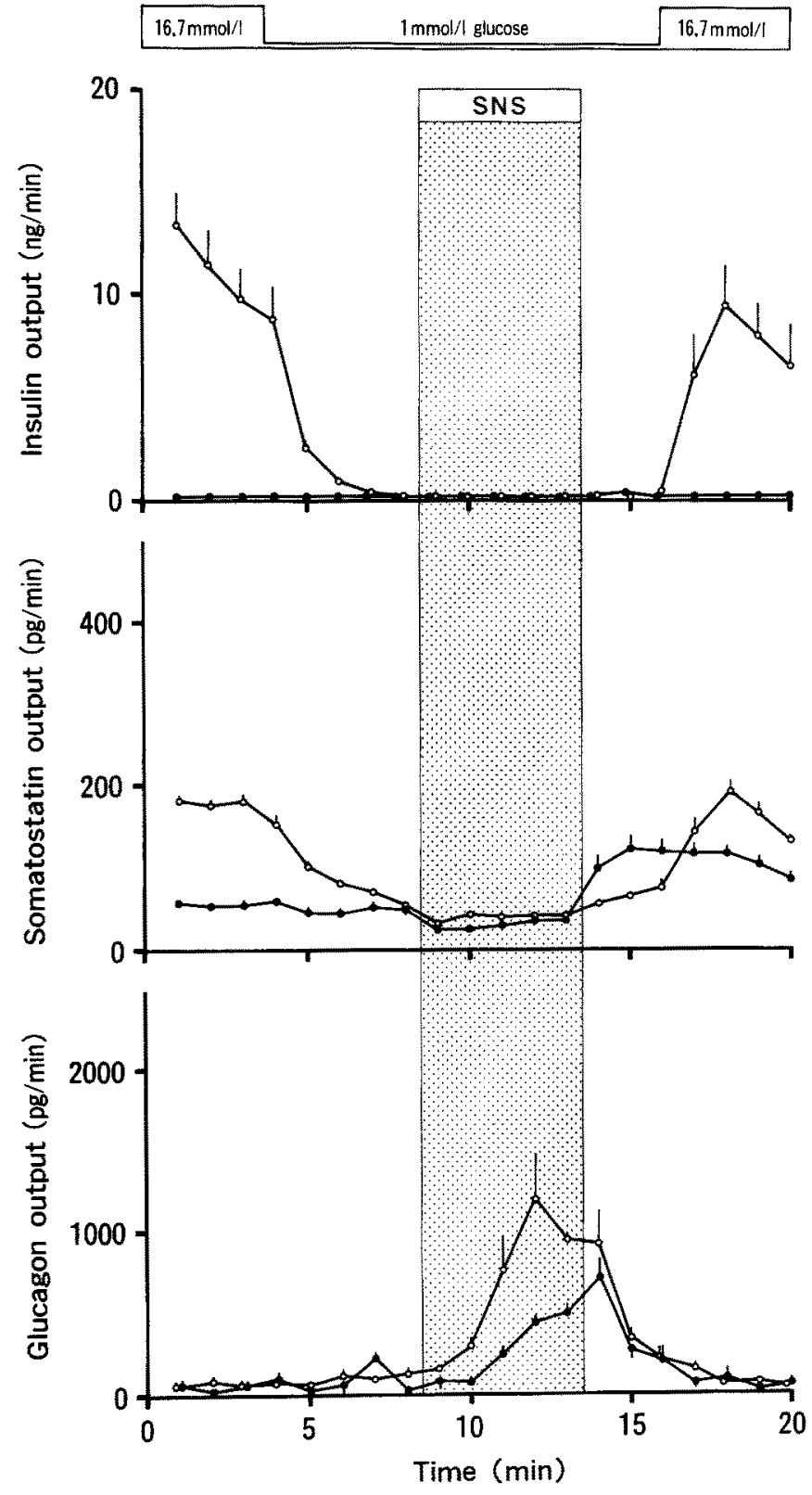

Fig. 4. Effects of splanchnic nerve stimulation (SNS) on insulin, somatostatin and glucagon secretion at $1 \mathrm{mmol} / \mathrm{l}$ glucose in rats treated with streptozotocin as adults $(\bullet)(n=5)$ and in control rats $(0-0)(n=6)$ using the isolated and perfused pancreas. Mean \pm standard error are shown

high glucose concentration. Although differences were found in the baseline insulin level between the NSZ rats and the control rats, the sensitivity of Beta cells to SNS in the NSZ rats may be enhanced, because the percentage decrease in the flow was not altered in the NSZ rats. Furthermore, in a recent study using the isolated islets of NSZ rats, the sensitivity of Beta cells to $\alpha_{2}$-adrenergic activation was reported to be increased [26].

The response of Delta cells to SNS appears to be blunted in the NSZ rats. However, Delta cells in the STZ rats responded normally to SNS. The reason for this discrepancy is not known, but a paracrine Beta-Delta cell interaction may be related to this blunted Delta-cell re- sponse in the Type 2 diabetes model. Kadowaki et al. [14] have reported previously that increased content and release of somatostatin in streptozotocin-induced diabetic rats correlated with the reduced Beta-cell mass. If remaining Beta cells have a suppressive effect on Delta cells in the NSZ rats with moderately decreased Beta-cell mass, reduction in a suppressive effect of insulin on Delta cells may be induced by hypersensitivity of the diabetic Beta cells to SNS. On the other hand, in the STZ rats with an extremely reduced number of Beta cells, the sensitivity of Beta cells to SNS was apparently unchanged, and the effect of insulin on pancreatic Delta cells was negligible because of the extremely reduced basal insulin secretion. This may explain why the percent decrease of somatostatin secretion induced by SNS was normal. Although we cannot exclude other possibilities including altered catecholamine sensitivity of diabetic Delta cells and paracrine Alpha-Delta cell interactions, diabetic Delta cells are possibly insensitive to sympathetic neural outflow in relation to the increased sensitivity of Beta cells to SNS.

In summary, our present study suggests that the sensitivity of diabetic Alpha and Delta cells to sympathetic neural activation are blunted, whereas the sensitivity of diabetic Beta cells to sympathetic neural activation is enhanced in the diabetic animal model.

Acknowledgements. This study was supported by Grants-in-Aid for Scientific Research from the Ministry of Education, Science, and Culture, and by the Research Committee of Experimental Models or Intractable Diseases of the Ministry of Health and Welfare of Japan, and also by a grant for diabetes research from Otsuka Pharmaceutical Co., Ltd. We thank Ms. T.Sokai, Ms. H. Tachikawa, and Mr. M. Ohno for their skilled technical assistance.

\section{References}

1. Cryer PE (1980) Physiology and pathophysiology of the human sympathoadrenal neuroendocrine system. N Engl J Med 303: 436-444

2. Gerich JE, Lorenzi M, Tsalikian E, Karam JH (1976) Studies on the mechanism of epinephrine-induced hyperglycemia in man. Evidence for participation of pancreatic glucagon secretion. Diabetes 25: 65-71

3. Unger RH, Orci L (1981) Glucagon in the pathogenesis of diabetes mellitus: the bihormonal abnormality hypothesis. In: Unger RH, Orci L (eds) Glucagon. Elsevier, New York, pp 369 376

4. Unger RH, Aguilar-Parada E, Müller WA, Eisentraut AM (1970) Studies of pancreatic alpha cell function in normal and diabetic subjects. J Clin Invest 49: 837-848

5. Portha B, Levacher C, Picon L, Rosselin G (1974) Diabetogenic effect of streptozotocin in the rat during the perinatal period. Diabetes 23: 889-895

6. Weir GC, Clore ET, Zmachinski CJ, Bonner-Weir S (1981) Islet secretion in a new experimental model for non-insulin-dependent diabetes. Diabetes 30:590-595

7. Rerup CC (1970) Drugs producing diabetes through damage of the insulin secreting cells. Pharmacol Rev 22: 485-518

8. Kurose T, Seino Y, Nishi S et al. (1990) Mechanism of sympathetic neural regulation of insulin, somatostatin, and glucagon secretion. Am J Physiol 21: E220-E227

9. Desbuquois B, Aurbach GD (1971) Use of polyethylene glycol to separate free and antibody-bound peptide hormones in radioimmunoassays. J Clin Endocrinol Metab 33: 732-738 
10. Seino S, Sakurai H, Seino Y et al. (1980) Starvation-induced changes of somatostatin, glucagon, and insulin secretion from the isolated perfused rat pancreas. Diabetes 29: 323-325

11. Arimura A, Sato H, Coy DH, Schally AV (1975) Radioimmunoassay for GH-release inhibiting hormone. Proc Soc Exp Biol Med 148: 784-789

12. Sakurai H, Imura H (1973) Radioimmunoassay of glucagon. Jpn J Nucl Med 10: 135-136

13. Duncan DB (1955) Multiple range and multiple F tests. Biometrics 11: $1-42$

14. Kadowaki S, Taminato T, Chiba T et al. (1980) Somatostatin release from the isolated, perfused diabetic rat pancreas. Inverse relationship between pancreatic somatostatin and insulin. Diabetes 29:960-963

15. Schmidt RE, Plurad SB, Modert CW (1983) Experimental diabetic autonomic neuropathy characterization in streptozo" tocin-diabetic Sprague-Dawley rats. Lab Invest 49:538-552

16. Anderson LC, Garrett JR, Thulin A, Proctor GB (1989) Effects of streptozotocin-induced diabetes on sympathetic and parasympathetic stimulation of parotid salivary gland function in rats. Diabetes 38: 1381-1389

17. Sidenius $P$ (1982) The axonopathy of diabetic neuropathy, Diabetes 31:356-363

18. Leahy J, Weir GC (1985) Unresponsiveness to glucose in a streptozotocin model of diabetes. Inappropriate insulin and glucagon responses to a reduction of glucose concentration. Diabetes 34: 653-659

19. Weir GC, Knowlton SD, Atkins RF, McKennan KX, Martin DB (1976) Glucagon secretion from the perfused pancreas of streptozotocin-treated rats. Diabetes 25:275-282

20. Tominaga $M$, Maruyama $H$, Vasko $M R$, Baetens $D$, Orci L, Unger RH (1987) Morphologic and functional changes in sympathetic nerve relationships with pancreatic Alpha cells after destruction of $\beta$-cells in rats. Diabetes 36:365 373
21. Tomlinson DR, Gillon KRW, Smith MG (1982) Axonal transport of noradrenaline and noradrenergic transmission in rats with streptozotocin-induced diabetes. Diabetologia 22: 199-204

22. Buchanan KD, Mawhinney WAA (1973) Glucagon release from isolated pancreas in streptozotocin-treated rats. Diabetes 22: $797-800$

23. Tominaga M, Maruyama $\mathrm{H}$, Bolli $\mathrm{G}$, Helderman $\mathrm{JH}$, Unger $\mathrm{RH}$ (1986) Simulation of the normal glucopenia-induced decline in insulin partially restores the glucagon response to glucopenia in isolated perfused pancreata of streptozotocin-diabetic rats. Endocrinology 118: 886-887

24. Giroix M, Portha B, Kergoat M, Bailbe D, Picon L (1983) Glucose insensitivity and amino-acid hypersensitivity of insulin release in rats with non-insulin-dependent diabetes. A study with the perfused pancreas. Diabetes 32: 445-451

25. Halter JB, Graf RJ, Porte D Jr (1979) Potentiation of insulin secretory responses by plasma glucose levels in man: evidence that hyperglycemia in diabetes compensates for impaired glucose potentiation. J Clin Endocrinol Metab 48: 946-954

26. Östenson C-G, Cattaneo AG, Doxey JC, Efendic S (1989) $\alpha$-Adrenoceptors and insulin release from pancreatic islets of normal and diabetic rats. Am J Physiol 257: E439-E443

Received: 13 May 1992

and in revised form: 21 July 1992

Dr. Y.Seino

Department of Metabolism and

Clinical Nutrition

Kyoto University Faculty of Medicine

54 Shogoin Kawahara-cho

Sakyo-ku

Kyoto 606

Japan 